\title{
Job Creation, a Mission Impossible? The South African Case
}

\section{Daniel Francois Meyer}

North-West University, South Africa

Doi:10.5901/mjss.2014.v5n16p65

\begin{abstract}
Jobs are the foundation of any economy. High levels of unemployment relate to a structural weakness in a country's economy and could lead to poverty, inequality, social problems and even in extreme cases, a regime change. South Africa has relatively high levels of unemployment with a rate of more than 25 percent. This article aims to analyse the status quo regarding job creation and unemployment in South Africa, analysing aspects such as theory and the current reality regarding employment and government policies. The article concludes with eight integrated solutions to job creation. Possible solutions include a shared vision, effective leadership, reform regarding the relaxation of labour regulations, improved education and skills training, the improvement of the business and development environment, improved government policy implementation and service delivery, entrepreneurship development, sectoral specific economic development, and research and development. The war on unemployment requires an integrated approach and all eight solutions need to be implemented concurrently. If high levels of coordination could be achieved, jobs could be created, leading to rapid economic development.
\end{abstract}

Keywords: Job creation, unemployment, economic policy, poverty, South Africa.

\section{Introduction}

"Jobs are the cornerstone of economic and social development" (World Bank, 2013). The impact of high levels of unemployment is devastating, resulting in poverty, social exclusion, inequality, crime and social instability (Kingdon and Knight, 2004). In South Africa, only 60 percent of all households obtain income by means of any kind of work, while 40 percent of households obtain income by means of government welfare payments (Schussler, 2013). The creation of jobs has been a challenge globally, but especially in South Africa. Unemployment rates in South Africa have escalated to a new peak of 25.2 percent (StatsSA, 2013c), compared to a global average of 9.2 percent in 2013 (CIA World Fact Book, 2013). South Africa has one of the highest unemployment rates in the world, and unemployment is the most pressing policy challenge facing government (CDE, 2013). It is the aim of this article to analyse the complex issues regarding job creation in South Africa and to find possible solutions to the problem of unemployment. Unemployment, in the end, leads to both economic and social-welfare problems such as high levels of poverty and inequality (The Presidency, 2011).

Since 1994, unemployment has been a growing problem in South Africa. The official rate of unemployment has increased from 17 percent in 1994, to a current rate of over 25 percent (StatsSA, 2013c). In terms of the Millennium Development Goals (MDG) (UNDP, 2010), all of the eight goals could be related to development. Specifically, Goal 1: Eradication of extreme poverty and Goal 8: Development of a global partnership for development, address the developmental problems of developing countries, and the development of strategies for creation of decent jobs and productive work opportunities. The country is doing well in terms of percentage investment share in the gross domestic product (GDP), the debt to gross national income (GNI) rate, and research and development as a percentage of the GDP. However, the country will not achieve most of the MDG regarding eradication of poverty, improved Gini-coefficient, improved employment to population ratio, and an increase in GDP per capita.

The obvious solution to unemployment, poverty and inequality, as identified in the National Development Plan (NDP), is the creation of jobs (The Presidency, 2011). Since 2011, in the last three State of the Nation addresses (SONA), job creation has remained the main priority of government (Zuma, 2011). Globally there is a trend of "jobless growth" where economic growth occurs without the creation of accompanying additional jobs (Matthews, 2012). This situation needs to the analysed, as well as the dualism regarding job opportunities. There seems to be an oversupply of unskilled, low-income jobs seekers versus an under supply of skilled workers demanding high income (Frost, 2002). The theory and practical implications of these issues will be analysed.

This article analyses some economic theories relating to job creation and employment, the current reality and trends in South Africa regarding jobs and unemployment, and a survey of the main policies affecting job creation in South Africa. The article will be concluded with the formulation of possible solutions for job creation in South Africa. 


\section{Theory of Unemployment and Job Creation}

As with most economic concepts, unemployment and job creation could also be explained by supply and demand. Therefore, unemployment is the situation where the supply of labour exceeds its demand. Unemployment could also mean the price of labour is too high. Wages are very difficult to push downwards and therefore high levels of unemployment can persist in the long run. It is also possible that significant vacancy rates and high unemployment rates can co-exist due to the lack of a suitably skilled labour force, which is also the case in South Africa (King, 2009).

Of the two main economic "evils" - inflation and unemployment - the latter has the most devastating impact on society, and is the cause of problems such as poverty, crime, social disunity and political uprisings. Research has indicated that education, skills training, health services, access to opportunities and transport have a positive impact on economic development and employment (Kooros, 2008).

Jobs are created by the private sector within enabling environments created by governments. Government policy should be based on three pillars namely, firstly the provision of a foundation or fundamentals such as a macro-economic stability, rule of law and human capital development, secondly, the formulation and implementation of acceptable labour regulations, and lastly, setting of developmental priorities. Mal-functioning labour regulations will prevent economic growth and job creation. Globally the private sector creates nine out of every ten jobs. Factors such as demographics, urbanisation, globalisation, technology and macro-economic failures create job challenges. The main benefit of the creation of jobs is increased living standards (World Bank, 2013).

Traditionally, rapid and sustained economic growth has been seen as the solution to job creation. It was also thought that rapid growth would automatically lead to increased quality of life and social cohesion. But, it has been proven that economic growth, an increase in living standards, and social cohesion changes grow at different rates. Economic growth, therefore, does not necessarily lead to a reduction in poverty levels. An economic development strategy needs to ensure inclusive growth and have a "pro-poor" focus (World Bank, 2013).

Okun's Law (Okun, 1962) explains the theory behind the relationship between economic growth and employment growth. This law from the 1960s states that a one percent increase in the GDP will result in a 0.3 percent decrease in unemployment. Recent studies have indicated that jobless growth is the norm, especially if labour regulations are not flexible. Another theory to predict employment growth is the growth elasticity of employment theory. This theory relates to the ratio between the percentage change in employment and the percentage change in GDP (World Bank, 2013; Fuhrmann, 2013).

According to the World Bank (2013), "The creation of jobs leads to development". This statement is justified through the quantification of the impact of jobs on development by listing the following aspects:

- Improved living standards as a result of earnings and income

- Poverty reduction

- Improved productivity

- Increased agglomeration effects

- Global integration

- Social cohesion through the creation of social identity, networks and a sense of belonging and fairness.

The levels of education and skills are in direct relation to employment opportunities and earning. Education and knowledge assists entrepreneurship development. A global problem is skill mismatches, which is a growing problem (World Bank, 2013). Youth unemployment is also a global problem with youth unemployment rates usually between two to three times that of the overall unemployment rate of a country. Youth jobs are usually of poor quality, low earning and temporary in nature (World Bank, 2013).

South Africa is affected by structural unemployment in most sectors of the economy, although not in all the sectors of the economy. This type of unemployment occurs where the quantity of labour supplied exceeds the quantity of labour demanded. The unemployed may lack the necessary skills required to fill the limited jobs that are available. Structural unemployment is more permanent of nature, and could only be resolved over the long run. Due to the long-term nature of this type of unemployment, many people become disheartened, give up looking for work, and also lose their skills over time (Calvin and Coetzee, 2010).

At the point where high levels of unemployment have settled, stabilisation policies are required and can play a major role in turning the situation around. The impact of globalisation and technological changes and advancement has a huge negative impact, especially on the lower-skilled labour force. Government must monitor labour supply and demand, and should react immediately to shocks before high levels of unemployment are established. High unemployment levels require a welfare state, but such a state could not be sustainable over the long run (Beissinger and Moeller, 2000). 


\section{Analysis of Status Quo of Jobs and Unemployment in South Africa}

Globally 200 million people are unemployed in terms of the narrow definition of unemployment and only 27 percent of all employable people have jobs that pay a monthly salary (World Bank, 2013). South Africa contributes approximately 2.3 percent to the world's unemployment and only 0.8 percent of the total world population. In South Africa, only 18 percent of the working age population (economically active) earn a monthly salary (CDE, 2012). In 1994, at the time of democratic transition, unemployment stood at 13 percent, and by 2000, that rate had increased to 30 percent, with a rate of 25.3 percent in 2013. A total of 75 percent of the unemployed are unskilled (Banerjee et al, 2006). Table 1 is a summary of unemployment rates of various countries as in 2014. Although South Africa has a relatively high unemployment rate, its rate is not the highest in the world. Most Southern African countries such as Zimbabwe, Namibia and Lesotho have higher rates. If the unemployment situation in Europe is analysed, the average unemployment rate in the Euro zone is 11.9 percent. Spain and Greece are examples of a few European countries with relatively high unemployment rates. Most European countries have experienced an increase in unemployment over the last few years (Country economy, 2014).

Table 1: International unemployment comparisons: 2014

\begin{tabular}{|l|c|c|c|c|c|}
\hline Country & Unemployment rate & Country & Unemployment rate & Country & Unemployment rate \\
\hline South Africa & $24.9 \%$ & Russia & $5.4 \%$ & Angola & $7.6 \%$ \\
\hline Argentina & $7.1 \%$ & Spain & $25.6 \%$ & Botswana & $17.2 \%$ \\
\hline China & $4.1 \%$ & Turkey & $9.0 \%$ & Ethiopia & $20.5 \%$ \\
\hline Egypt & $12.6 \%$ & US & $8.1 \%$ & Lesotho & $28.3 \%$ \\
\hline India & $9.8 \%$ & Brazil & $5.8 \%$ & Mozambique & $7.6 \%$ \\
\hline Euro zone & $11.9 \%$ & Greece & $27.5 \%$ & Croatia & $17.6 \%$ \\
\hline Romania & $7.2 \%$ & Poland & $9.7 \%$ & Slovakia & $13.9 \%$ \\
\hline Japan & $4.4 \%$ & Indonesia & $6.3 \%$ & Namibia & $37.5 \%$ \\
\hline Mexico & $5.0 \%$ & Thailand & $1.0 \%$ & Zambia & $15.8 \%$ \\
\hline
\end{tabular}

Source: Country economy, 2014.

In addition, South Africa is compared with a typical east European country namely Romania regarding some of the key economic indicators (see table 2). The two countries are very similar, except for the rate of unemployment. Romania has a relatively low unemployment rate, below the average of the Euro Zone. The two countries have similar GDP per capita data. While Romania has better HDI data, South Africa has a higher competitiveness ranking than Romania. Both countries have negative trade balances. The main challenges for economic growth and job creation in Romania are exports markets with European partners and political development in Europe (World Bank, 2014).

Table 2: Key indicators: South Africa versus Romania

\begin{tabular}{|l|c|c|}
\hline Key indicator & South Africa & Romania \\
\hline GDP per capita & $\$ 7508$ & $\$ 7939$ \\
\hline Unemployment rate & $24.9 \%$ & $7.2 \%$ \\
\hline Trade balance (in millions) & $-\$ 36988$ & $-\$ 12359$ \\
\hline HDI & 0.63 & 0.79 \\
\hline Competitiveness ranking & 53 & 76 \\
\hline
\end{tabular}

Source: Country economy, 2014

Table 3 is a summary of overall employment data for South Africa. In total, 4609000 people are unemployed, with an official unemployment rate of 24.7 percent. Only 15.6 percent of all employed people are employed in the informal sector (StatsSA, 2013c). Since 2001 to 2013 the total number of employed people has increased by 3.9 percent, while the total unemployed increased by 4.0 percent. South Africa's labour absorption rate compares poorly with European countries. The informal sector specifically has a very low contribution to employment in South Africa, especially if compared to the other developing countries in the BRICS group. 
Table 3: Employment data for South Africa: 2001 to 2013

\begin{tabular}{|l|c|c|c|c|}
\hline \multicolumn{1}{|c|}{ Factor } & $\mathbf{2 0 0 1}$ & $\mathbf{2 0 1 1}$ & $\mathbf{2 0 1 2}$ & $\mathbf{2 0 1 3}$ \\
\hline Total employed & 12494000 & 13125000 & 13447000 & 14029000 \\
\hline Formal sector employed (contribution to total employment in brackets) & $\begin{array}{c}6984000 \\
(55.9 \%)\end{array}$ & $\begin{array}{c}9198000 \\
(70.1 \%)\end{array}$ & $\begin{array}{c}9571000 \\
(71.2 \%)\end{array}$ & $\begin{array}{c}10008000 \\
(71.3 \%)\end{array}$ \\
\hline Informal sector employed (contribution to total employment in brackets) & $\begin{array}{c}3353000 \\
(26.8 \%)\end{array}$ & $\begin{array}{c}2213000 \\
(16.9 \%)\end{array}$ & $\begin{array}{c}2085000 \\
(15.5 \%)\end{array}$ & $\begin{array}{c}2182000 \\
(15.6 \%)\end{array}$ \\
\hline Employed in agriculture (contribution to total employment in brackets) & $\begin{array}{c}968000 \\
(7.7 \%)\end{array}$ & $\begin{array}{c}598000 \\
(4.6 \%)\end{array}$ & $\begin{array}{c}638000 \\
(4.7 \%)\end{array}$ & $\begin{array}{c}706000 \\
(5.0 \%)\end{array}$ \\
\hline Employed in private households (contribution to total employment in brackets) & $\begin{array}{c}1188000 \\
(9.5 \%)\end{array}$ & $\begin{array}{c}1117000 \\
(8.5 \%)\end{array}$ & $\begin{array}{c}1153000 \\
(8.5 \%)\end{array}$ & $\begin{array}{c}1132000 \\
(8.1 \%)\end{array}$ \\
\hline Total unemployed & 4081000 & 4538000 & 4470000 & 4609000 \\
\hline Official unemployment rate & $24.6 \%$ & $25.7 \%$ & $24.9 \%$ & $24.7 \%$ \\
\hline Unofficial unemployment rate & $31.7 \%$ & $36.9 \%$ & $36.2 \%$ & $36.1 \%$ \\
\hline Labour absorption rate & $45.8 \%$ & $40.5 \%$ & $40.9 \%$ & $41.9 \%$ \\
\hline
\end{tabular}

Source: StatsSA, (2013b).

If compared to Okun's Law, since 1970 to 2000, for each one percent (1\%) increase in economic growth (GDP), employment grew equally by one percent (1\%). Over the last decade, a one percent (1\%) increase in economic growth (GDP) has led to only a 0.4 percent increase in jobs created in South Africa (CDE, 2010). Table 4 provides an indication of the jobless growth occurring in South Africa. For example, in 2010 a 2.8 percent growth in GDP, led to a negative employment growth of -2.3 percent and unemployment growth of 6.7 percent.

Table 4: "Jobless" growth in South Africa

\begin{tabular}{|c|c|c|c|c|c|}
\hline Year & $\begin{array}{c}\text { Number of people } \\
\text { employed }\end{array}$ & $\begin{array}{c}\text { Year on year change } \\
\text { in employment }\end{array}$ & $\begin{array}{c}\text { Number of people } \\
\text { unemployed }\end{array}$ & $\begin{array}{c}\text { Year on year change in } \\
\text { unemployment }\end{array}$ & $\begin{array}{c}\text { Real GDP } \\
\text { growth }\end{array}$ \\
\hline 1995 & 8069000 & $1.2 \%$ & 1644000 & $-17.3 \%$ & $3.1 \%$ \\
\hline 1996 & 7590000 & $-5.9 \%$ & 2019000 & $22.8 \%$ & $4.3 \%$ \\
\hline 1998 & 9390000 & $24.4 \%$ & 3163000 & $41.3 \%$ & $0.5 \%$ \\
\hline 2000 & 11880000 & $14.6 \%$ & 4333000 & $37.2 \%$ & $4.2 \%$ \\
\hline 2002 & 11995000 & $-4.0 \%$ & 4603000 & $12.8 \%$ & $3.7 \%$ \\
\hline 2004 & 11823000 & $1.3 \%$ & 4231000 & $-12.6 \%$ & $4.6 \%$ \\
\hline 2006 & 13237000 & $5.9 \%$ & 3984000 & $-0.2 \%$ & $5.6 \%$ \\
\hline 2008 & 13729000 & $3.7 \%$ & 4114000 & $-0.1 \%$ & $3.6 \%$ \\
\hline 2010 & 13061000 & $-2.3 \%$ & 4401000 & $6.7 \%$ & $2.8 \%$ \\
\hline 2012 & 13447000 & $2.5 \%$ & 4470000 & $-1.5 \%$ & $2.7 \%$ \\
\hline
\end{tabular}

Source: Holborn, (2012)

Table 5 is a summary of unemployment data per age group in 2012. The majority of the unemployed are aged between 15 to 34 years, relating to a total of over 80 percent. Youth unemployment is a major problem and needs to be addressed. In 2014 the Employment Tax Incentive Bill was released. This piece of legislation has the aim to promote youth employment and is further discussed in the policy review section (section 4).

Table 5: Unemployment by age groups in South Africa, 2012

\begin{tabular}{|c|c|c|c|c|}
\hline Age categories & $\begin{array}{c}\text { People unemployed, } \\
\text { official definition }\end{array}$ & $\begin{array}{c}\text { Official } \\
\text { unemployment rate }\end{array}$ & $\begin{array}{c}\text { People unemployed, } \\
\text { narrow definition (\%) }\end{array}$ & $\begin{array}{c}\text { Unofficial unemployment rate, } \\
\text { expanded definition (\%) }\end{array}$ \\
\hline 15-24 years & 1291000 & 2433000 & $51.5 \%$ & $66.7 \%$ \\
\hline $\mathbf{2 5 - 3 4}$ years & 1870000 & 2957000 & $29.3 \%$ & $39.6 \%$ \\
\hline 35-44 years & 864000 & 1394000 & $17.8 \%$ & $25.9 \%$ \\
\hline 45-54 years & 364000 & 653000 & $12.5 \%$ & $20.4 \%$ \\
\hline 55-64 years & 80000 & 185000 & $6.4 \%$ & $3.7 \%$ \\
\hline Total & 4470000 & 7623000 & $24.9 \%$ & $36.2 \%$ \\
\hline
\end{tabular}

Source: Holborn, (2012) 
The poor state of the education system also plays a role in unemployment, especially regarding the youth and unskilled; for example, the unemployment rate for youths without grade 12 is three times higher than for people who completed grade 12 (CDE, 2012). Due to the high levels of unemployment and poverty, South Africa has moved towards being a welfare state. The welfare system in South Africa is now well established, but a welfare system can never fill the gap left by unemployment. A total of 5.4 million tax payers need to subsidise more than 16 million people receiving social grants, relating to a ratio of one tax payer supporting three social grant beneficiaries (CDE, 2012).

According to Ramaphosa (2013), youth unemployment is a phenomenon that is growing due to lack of skills, training, experience and lack of support to release their entrepreneurial potential. Other reasons for not employing the youth are high minimum salaries, and labour laws. Unemployment and low skills levels are related. Table 6 is a summary of social welfare grant beneficiaries in 2012.

Table 6: Social grants beneficiaries in South Africa: 2012

\begin{tabular}{|l|c|c|c|}
\hline Type of grant & Number of beneficiaries & $\begin{array}{c}\% \text { contribution to number of } \\
\text { beneficiaries }\end{array}$ & $\begin{array}{c}\% \text { contribution to social } \\
\text { grant budget }\end{array}$ \\
\hline Old-age pension & 2772745 & $17 \%$ & $39 \%$ \\
\hline War veterans & 706 & $0.1 \%$ & $0.1 \%$ \\
\hline Disability & 1192444 & $7 \%$ & $18 \%$ \\
\hline Foster care & 671307 & $4 \%$ & $6 \%$ \\
\hline Care dependency & 131246 & $1 \%$ & $2 \%$ \\
\hline Child support & 11300559 & $70 \%$ & $36 \%$ \\
\hline Total & 16069007 & $100 \%$ & R 7.9 billion \\
\hline
\end{tabular}

Source: National Treasury, (2012)

The private sector provides for 86 percent of all employment and government provides for the remaining 14 percent. Only 41 percent of all economically active people are employed. Youth unemployment is extremely high at more than 50 percent. Youth unemployment relates to 3.2 million people between the ages of 15 to 34 in terms of the narrow definition of unemployment. South Africa has high levels of unemployment, up to 35 percent in terms of the broad definition of unemployment, with low levels of economic growth (CDE, 2013; CDE, 2012).

Table 7 provides a comparison of economic sectors regarding number of employees and income from 2009 to 2013. From the data, it shows that all sectors have shown low growth, and the main sectors, such as manufacturing and construction, have even shown negative growth. Growth in income has been above that of inflation regarding all sectors.

Table 7: Economic sector comparison in South Africa: 2009 to 2013

\begin{tabular}{|c|c|c|c|c|c|c|}
\hline \multirow[t]{2}{*}{ Sector } & \multicolumn{2}{|c|}{ Number of employees } & \multirow{2}{*}{$\begin{array}{c}\text { Growth in number } \\
\text { of employees } \\
2009-2013(\%)\end{array}$} & \multicolumn{2}{|c|}{$\begin{array}{l}\text { Average income in } \\
\text { Rand }\end{array}$} & \multirow{2}{*}{$\begin{array}{c}\text { Growth in income } \\
2009-2013(\%)\end{array}$} \\
\hline & 2009 & 2013 & & 2009 & 2013 & \\
\hline Mining & 500000 & 515000 & 0.7 & 10348 & 15562 & 10.7 \\
\hline Manufacturing & 1239000 & 1148000 & -1.9 & 8547 & 12810 & 10.6 \\
\hline Electricity, gas, etc & 60000 & 62000 & 0.8 & 19481 & 28585 & 10.1 \\
\hline Construction & 458000 & 432000 & -1.5 & 6672 & 10533 & 12.1 \\
\hline Wholesale, trade, hotel, rest. & 1681000 & 1689000 & 0.1 & 6570 & 9168 & 8.7 \\
\hline Transport, storage, communication & 362000 & 380000 & 1.2 & 12368 & 17593 & 9.2 \\
\hline Finance, insurance, business services & 1863000 & 1841000 & 0.3 & 10737 & 14502 & 7.8 \\
\hline Community, social and personal services & 2163000 & 2398000 & 2.6 & 11132 & 16596 & 10.5 \\
\hline Total & 8326000 & 8465000 & 0.4 & 9614 & 13908 & 9.7 \\
\hline
\end{tabular}

Source: StatsSA, (2013c)

Traditional economic sectors such as manufacturing have declined regarding their contribution towards job opportunities if compared to jobs created in the services sector. More and more workers are in temporary employment with no fixed monthly income (The Presidency, 2011). If the economic sectors are further analysed regarding employment, the financial services sector employment has increased as well as community, social and household services, while sectors 
such as manufacturing and construction have shed jobs over the last decade (CDE, 2013). In South Africa, since 2008, before the recession started, manufacturing jobs have been lost while services jobs (sales and services) have increased by the same amount of approximately 300000 jobs over a 3 year period. Current trends are towards knowledge or skills intensive, and services economy. An important aspect regarding the job market is that there is an oversupply of unskilled workers with low income levels and a shortage in highly skilled highly paid workers. This situation is especially affecting the youth, and linked to this situation, the low levels of self-employment and entrepreneurship (CDE, 2013).

Table 8 is a summary of the percentage employment contribution per economic sector. The informal sector has shrunk from 2001 to 2012, and the traditional sectors of agriculture and mining have shown negative growth rates. The sectors of construction and finance have shown relative high growth rates.

Table 8: Contribution to total employment per economic sector

\begin{tabular}{|l|c|c|c|c|c|}
\hline Sector & $\begin{array}{c}\text { \% contribution in } \\
\mathbf{2 0 0 1}\end{array}$ & $\begin{array}{c}\text { \% contribution in } \\
\mathbf{2 0 1 2}\end{array}$ & $\begin{array}{c}\text { Total employ- } \\
\text { ment in 2012 }\end{array}$ & $\begin{array}{c}\text { Change in number of } \\
\text { jobs from 2001 to 2012 }\end{array}$ & $\begin{array}{c}\text { \% growth in sector } \\
\text { from 2001 to 2012 }\end{array}$ \\
\hline Total formal employment & $55.9 \%$ & $71.2 \%$ & 9571000 & 2587000 & $2.9 \%$ \\
\hline Total informal employment & $26.8 \%$ & $15.5 \%$ & 2085000 & -1268000 & $-4.2 \%$ \\
\hline Agriculture & $7.7 \%$ & $4.7 \%$ & 638000 & -331000 & $-3.7 \%$ \\
\hline Mining & $3.9 \%$ & $2.7 \%$ & 357000 & -128000 & $-2.7 \%$ \\
\hline Manufacturing & $11.7 \%$ & $11.2 \%$ & 1507000 & 45000 & $0.3 \%$ \\
\hline Utilities & $0.6 \%$ & $0.7 \%$ & 97000 & 20000 & $2.1 \%$ \\
\hline Construction & $2.7 \%$ & $5.3 \%$ & 719000 & 377000 & $6.9 \%$ \\
\hline Trade & $10.9 \%$ & $14.6 \%$ & 1965000 & 600000 & $3.4 \%$ \\
\hline Transport & $3.9 \%$ & $4.5 \%$ & 604000 & 111000 & $1.9 \%$ \\
\hline Finance & $7.9 \%$ & $11.9 \%$ & 1605000 & 617000 & $4.5 \%$ \\
\hline $\begin{array}{l}\text { Community and social } \\
\text { services }\end{array}$ & $14.2 \%$ & $20.2 \%$ & 2712000 & 940000 & $3.9 \%$ \\
\hline Private households & $9.5 \%$ & $8.6 \%$ & 1153000 & -35000 & $-0.3 \%$ \\
\hline
\end{tabular}

Source: StatsSA, (2013a).

The New Growth Path (NGP) the current macro-economic policy for South Africa, is analysed in the next section, but the "job drivers", as identified in the NGP, are discussed in terms of their status quo and potential for job creation and economic growth.

- Infrastructure: Since 2008, government has invested substantially in infrastructure, and this process will continue as a tool to combat low growth. Infrastructure development will also assist the construction industry. This sector will substantially contribute to job creation over the next decade.

- Mining: The mining sector is in a declining phase and recovery is not expected due to labour unrest and resource decline. The potential for job creation is limited.

- Agriculture: This sector has shown negative growth over the last two decades, but has potential to grow with policy support. The potential for job creation is substantial.

- Agro-processing: This sector, which is dependent on the agricultural sector and the manufacturing sector, has huge growth potential and needs to be supported through policy development.

- Manufacturing: This sector, in collaboration with the agro-processing sector, needs to be supported by policy and has been declining over the last decade. The sector is the cornerstone of economic development and has the potential to contribute substantially to job creation.

- Tourism: This sector has been growing at a rapid rate and this trend will continue and will contribute substantially to job creation in the future.

- Green economy: This sector of the economy links to other sectors such as agriculture, manufacturing and will contribute to job creation in future, subject to clear policy direction.

- Public service: This sector of the economy has grown over the last decade and the public sector should be restricted and should not be allowed to grow at the same rate of the last decade. A 'lean and mean' public service is required.

In terms of the World Economic Forum (WEF) Global Competitiveness Report (WEF, 2013), South Africa is ranked 53rd overall out of 148 countries. The country is ranked $28^{\text {th }}$ regarding market efficiency and only $95^{\text {th }}$ regarding the 
macro-economic environment. Other meaningful factors of concern include ease of doing business ranked $109^{\text {th }}$, health of the work force ranked $133 \mathrm{rd}$, and the quality of the education system ranked $146^{\text {th }}$. Labour specific rankings include, labour market efficiency at $116^{\text {th }}$, hiring and firing practices at 147 th, wages flexibility at $144^{\text {th }}$, and lastly, labour market labour-employer relations at $148^{\text {th }}$. Overall South Africa is struggling in "ease of doing business" according to the report.

The International Monetary Fund (IMF, 2013), states South Africa needs structural reforms to boost growth and create employment. South Africa's growth rate is below that of other emerging markets. Major concerns for the local economy are labour unrest and electricity capacity. Reforms need to focus on improved education, reduction in transport costs, enhanced competitiveness and labour regulations.

South Africa is a world leader regarding wage related labour strikes. Global lessons indicate that too rapid increases in wages will have a negative impact on employment growth (CDE, 2013). According to Kingdon and Knight (2005), the labour market and regulations hold the key to South Africa's prosperity. Restrictive labour policies and legislation include the Labour Relations Act of 1995, the Basic Conditions of Employment Act of 1997, the Employment Equity Act of 1998, the Skills Development Act of 1998 and the Skills Development Levies Act of 1999 (CDE, 2013).

Chandra et al. (2002) found that factors such as crime, access to credit, access to infrastructure, and training are stumbling blocks for informal traders to enter the market. These factors could however, also occur in other developing countries. Nevertheless, according to Kingdon and Knight (2005), South Africa's strict labour regulations place a huge burden on small firms and inhibit individual entrepreneurship. Apartheid also suppressed self-employment by means of legislation such as the Group Areas Act, licensing and by-laws.

The country's rate of intentional entrepreneurship is low at 14 percent compared to a global average of 27 percent, as well as the rate of established business at 2.3 percent compared to a global average of 8 percent. A relation exists between level of education and level of entrepreneurship (Turton and Herrington, 2012). Small business plays a major role on job creation. Up to 68 percent of all South Africans are employed by businesses of 50 or less employees, while 43 percent of the employed labour force are employed by businesses with five or fewer workers. The estimated 2.8 million SMME's contribute 55 percent of GDP and approximately 61 percent of total employment (Oosthuizen, 2013).

\section{South African Policy Review}

A few of the major government policies and legislation, which have an impact on employment and job creation, are discussed including the NDP, the New Growth Path (NGP), labour regulations, the Expanded Public Works Programme (EPWP), Industrial Policy Action Plan (IPAP), Comprehensive Rural Development Programme (CRDP), and the Community Works Programme (CWP).

The NDP of 2011 (The Presidency, 2011) listed nine main challenges that are facing the country; these include high levels of unemployment, poor quality of education, infrastructure development and maintenance, the spatial separation of communities, the unsustainable resource base of the economy, poor performance of public health services, unequal and poor service delivery, high levels of corruption and lack of social cohesion. The NDP strives to address these challenges through strong leadership, effective governance and active citizenry. The NDP (The Presidency, 2011) wants to address the high levels of unemployment and poverty as follows:

- Active labour market policies and incentives focusing on young people and low-skilled people with incentives and intensified training.

- Expansion of public works programmes as part of EPWP.

- Improve the quality of education and training.

- Integrated housing development to bring people closure to economic opportunities regarding jobs and transport.

- Monetary policy needs to ensure that low inflation and economic growth are balanced. Relative low interest rates and a weakened rand exchange rate could support export

- Social welfare safety nets must remain in place to protect the poor and unemployed

- Sectors with development potential such as the job-driver sectors, as listed in the NGP, should be supported

- Employment rates could be improved by better education and skills training, healthier population, improved infrastructure and a capable state.

- The creation of an enabling environment

- Promotion of job creation in labour-absorbing industries

- Export promotion and increased competitiveness

- Improved policy implementation 
- Improved partnership formation and cohesion.

The NDP plans to create jobs by improved economic policy, public/private partnerships, promotion of investment in labour intensive economic sectors, improving competitiveness, promoting export, improving labour market functionality, and improving skills linked to the requirements of business (The Presidency, 2011). The NDP aspires to create 11 million jobs by 2030, with an annual GDP growth rate of 5.4 percent.

According to the NDP (The Presidency, 2011), public employment schemes (PES) are important towards increased employment rates. In South Africa, the Expanded Public Works Programme (EPWP) and Community Works Programme (CWP) are the two main public employment schemes. The schemes need to employ or create 2 million job opportunities per year. The EPWP plays a major role in the government's job creation plans. According to McCord (2004), after an analysis of the success of EPWP projects, it was found that employment potential and opportunities were insufficient to provide the mass employment that is urgently needed, and the selection and targeting tools are inadequate. Table 9 is a summary of EPWP employment data from 2004 to 2012.

Table 9: EPWP employment data: 2004 to 2012

\begin{tabular}{|l|c|c|c|c|}
\hline Sector & Period from April 2004 to March 2009 & $\mathbf{2 0 0 9 / 2 0 1 0}$ & $\mathbf{2 0 1 0 / 2 0 1 1}$ & $\mathbf{2 0 1 1 / 2 0 1 2}$ \\
\hline Infrastructure & 955233 & 263457 & 277100 & 241 177 \\
\hline Non-state & & 60039 & 126848 & 113615 \\
\hline Environment and culture & 467720 & 95942 & 107189 & 80766 \\
\hline Social & 174366 & 206421 & 131979 & 144424 \\
\hline Economic & 20377 & & & \\
\hline Total & 1617696 & 625859 & 643116 & 549982 \\
\hline Average days of employment & $\mathrm{Na}$ & 49 & 34 & $\mathrm{Na}$ \\
\hline
\end{tabular}

Source: Holborn, (2102)

From the above table it could be stated that the EPWP has contributed to skills development and temporary job creation, but has had a limited impact on the unemployment rate and the average number of days of employment have been limited. The cost per job created was also expensive, and the implementation of the programme could improve for lowerlevel-skilled jobs, with on the job training.

Table 10 provides a summary of government efforts contributing to job creation.

Table 10: Government efforts to create jobs in 2012

\begin{tabular}{|l|c|}
\hline Programme & Budget \\
\hline General job creation programmes job fund & R 6.2 billion \\
\hline EPWP & R77.8 billion \\
\hline CWP & R 6.2 billion \\
\hline Working for water and Fire & $\mathrm{R} 7.7$ billion \\
\hline National Youth Service Corps (NYSC) & R 900 million \\
\hline Arts and culture & R 300 million \\
\hline
\end{tabular}

Source: Steyn, (2012)

The NGP was released in 2010, placing job creation at the centre of the national economic policy. The NGP has identified a number of job drivers such as infrastructure, mining, manufacturing, agriculture, agro-processing, tourism and the green economy. In collaboration with the NGP, the Industrial Development Corporation (IDC) has established the Green Industries Special Business Unit, with a five-year budget of R22 billion. It is estimated that 462000 jobs could be created in the green economy (Borel-Saladin and Turok, 2013). One of the labour intensive sectors, which is part of the job drivers, is the agricultural sector. This sector has been neglected, leading to rural decay in South Africa. The agriculture sector has contracted drastically over the past few decades in terms of employment and production. In 1971, formal employment in the sector was 1.8 million, and in 2012, it was just more than 600000 . This sector needs to play a larger role in economic development, especially in rural areas. Proposals to assist the growth of the sector include provision of infrastructure, improved linkages between commercial and small farmers, improved land reform processes, technological 
development, and improved policy implementation (The Presidency, 2011).

In September 2013, the long awaited "youth job subsidy bill", officially known as the Employment Tax Incentive Bill, was released. The overall goal of the bill is to accelerate job creation for the youth in South Africa. A total of 3.2 million youths between the ages of 15 to 35 are unemployed and this age group accounts for 72 percent of all unemployed people. The bill will provide tax incentives for employers to employ young people earning a salary of between R2 000 and R6 000 per month. Each such job would only cost the government approximately R37 000 over a two year period, compared to the EPWP, where the average cost per job is close to R100 000. The subsidy aims to lower the cost of employment to the employer. Evidence from other such programmes globally indicates that it will encourage job creation and reduce levels of poverty (CDE, 2011). The bill is criticised for the exclusion of existing workers, the fact that it will run for only two years and the limited budget allocated to the programme. The budget of R500 million needs to be increased to at least R1 billion over the period. The programme could make a difference if it could be extended in terms of budget allocation and time frame.

Taking into account the country's strict labour regulations, jobs created by the private sector are expensive with minimum wages, but unfortunately, productivity is relatively low resulting in "jobless growth" (CDE, 2011). In Asia, the approach was to expand the number of jobs created at all costs and at a rapid rate. This resulted in higher levels of productivity, and improved levels of quality of life. According to Rose (2013), the current "labour relations is South Africa's Achilles heel". Labour relations and regulations are contributors to the unemployment rate, slow growth and lack of investment by companies. South Africa can no longer be seen as a low-cost investment country, but as a high-risk labour environment with low productivity.

The Department of Trade and Industry (DTI) implement the Industrial Policy Action Plan (IPAP) for South Africa, in collaboration with the Industrial Development Corporation (IDC). The IPAP is informed by the NDP and NGP. The IPAP has the following focus areas, namely diversification of the economy, labour absorbing industrialisation, infrastructure development and the movement to a knowledge economy. The overall principles of the IPAP are to reverse the threat of deindustrialisation and improve value-adding and labour intensive sectors. Specific sectors that are supported include clothing, textiles, automotive products, plastics, metals fabrication, agro-processing, forestry, and creative industries. The IPAP has identified a number of threats regarding the strengthening of manufacturing in South Africa, which include the growing current account deficit, diminishing competitive advantages such as stable labour and high electricity prices, a reduction in demand for primary commodity exports, a weak skilled labour force and unstable labour relations (DTI, 2012).

Rural development is seen as a priority by government, and the Department of Rural Development and Land Reform (DRDLR) was established in 2009. The flagship programme of the department is the Comprehensive Rural Development Programme (CRDP). The CRDP has an integrative and comprehensive approach to rural development, consisting of the following pillars, namely agrarian transformation, land reform, socio-economic development of rural communities and the revitalisation of rural towns by the provision of social and economic infrastructure. The CRDP aims to train local rural communities to be entrepreneurial and to establish SMMEs (DRDLR, 2010). Implementation has been limited.

Another important government programme is the Community Works Programme (CWP), which was initiated in 2010 by the Department of Cooperative Governance and Traditional Affairs (COGTA). The aim of the programme is the placement of local community members as Community Development Workers (CDW) in all wards across South Africa. By 2011, 89689 CDWs had been deployed (The Presidency, 2011). The CWP provides job opportunities to local people in collaboration with the EPWP. Further aims of the programme are to create jobs, improve community participation and improve service delivery.

\section{Solutions}

The obvious solution to unemployment is to create new jobs. Any unemployment rate above 6 percent to 7 percent indicates a structural problem in the economy and assistance is required. The high rate of unemployment is wellentrenched, and successful policy intervention, as well as rapid economic development, is needed to turn the situation around. The government is expected to intervene with appropriate policies (Amadeo, 2013). An integrated and comprehensive war is required to fight unemployment and to create new jobs. Eight main solutions have been formulated from the previous section and are listed below. Due to the integrated nature of the eight solutions, if one solution is neglected, it will affect the total outcome.

A shared vision and leadership: Annually, the South African government presents its priority focus for the year in the state of the nation address (SONA). Since 2011, job creation has been the top priority. In support of the SONA, the 
NDP was released as a long-term development plan with a vision for the country. This plan needs to be accepted by all role players and the development priorities be implemented. Implementation of priorities such as job creation and export promotion, require strong leadership and well formulated policies, with enough detail to implement at the local sphere. Strong leadership includes monitoring and control. Policy approaches such as 'jobs for all' and youth job creation are required. Strong leadership direction is essential for economic development. For example in the US state of Tennessee, leadership resulted in solutions for the local economy and workforce. The goal was to ensure technology based ideas were converted into marketable products, resulting in job creation in the region (Hackler, 2008). McFarland (2011) also agrees that local leaders must direct local economies to adapt to changing environments. They need to initiate policy and programme, with partners such as local business and communities.

Labour legislation and regulations reform: Consensus exists regarding the fact that labour legislation and regulations need to be relaxed, even the NDP recommends it. Since 1995 with the promulgation of the Labour Relations Act, regulations have been tightened instead of relaxed. Global lessons indicate that flexible labour regulations promote economic growth and job creation. The aim should be for equal growth in wages and productivity, otherwise it becomes too expensive to hire people. Rapid wage increases are negative for employment growth. The liberal viewpoint is only to retain health and safety regulations and to abolish the rest of the labour regulations. The strict labour policies and regulations prevent large-scale private sector job creation. If employers are allowed to have more freedom regarding appointment and release of workers, the labour market will perform more efficiently. This will also allow a more competitive labour market leading to increases in productivity. Temporary employees also need to be allowed more easily (CDE, 2013). Labour market reforms should complement and support macro-economic policies to accelerate employment creation (OECD, 2010). A number of countries in Asia are battling unemployment and are winning the war. The key factor for success is flexible labour regulations, which will encourage employers to take in workers when needed. South Africa has rigid labour laws mostly found in developed countries with low unemployment rates. A direct relationship exists between rigidity of labour laws and the ability to create jobs. In India the state of West Bengal with its strict labour laws are growing at only 1.5\%, while Andhra Pradesh with more liberal labour laws are growing at $6 \%$. Strict labour laws can negate all government efforts to create jobs (Du Toit, 2012). In order to create masses of jobs for unskilled people in a 'jobs for all' approach, overkill regulations restrict job creation in formal, informal and temporary sectors. Jobs can be created if the employers risk is minimised regarding dismissal. A large number of jobs could be created starting at low wages with slow rising incomes (CDE, 2013).

Education and skills training: South Africa has an under-performing education system and the system does not produce pupils ready for the labour market. An education system tailor made for work must be designed. The right skills should be provided at school and university level to prevent skill mismatches. A balance should also be achieved between academic and practical training, with apprenticeships high on the agenda. Government, trade unions, business and civil society need to work together, especially to assist youth in entering the job market. A possible solution is government/business managed and funded job centres, which provide practical and theoretical training such as at vocational institutions. Skills could focus on what industry wants and the services required. This will allow students to either work for a business or have the required skills to start their own business. In the US, the federal government has identified the need for "collaborative exchange" between education and industry. The collaboration is initiated and funded by government with school-to-work programmes (Hackler, 2008). In the North-East Pennsylvania the regions workforce composition was transformed after a federal grant was implemented. In South Africa youth unemployment is more than $50 \%$ as a result of demand-side as the number of jobs created is low and the supply-side with most young South Africans lack the appropriate skills and qualifications required in a high-skills economy. In 2010 a total of 3.2 million youth were not in education, employment or training (Cloete and Butler-Adam, 2012).

Creation of an enabling business and development environment: Government must create and establish a positive environment for business to prosper, allowing a positive investment climate. This could be done by means of partnership formation, reduction of red tape regulations, comprehensive support for SMMEs and the informal sector, removal of barriers to enter into markets, infrastructure capacity, reduction of crime and improved access to credit. According to the United Nations Industrial Development Organization (UNIDO: 2008) one of the main reasons of lack of rapid economic development in the sub-Saharan region is a poor investment climate and business environment. Targeted policy interventions could include access to finance, technical training, provide business development services and support inter-firm specialization and innovation.

Government policies and service delivery: In terms of the World Economic Forum (WEF, 2011) report entitled, "The future of government", it is stated that the public service should be 'lean and mean', consisting of well trained professional people, doing more with less. Since 2005, 250000 officials have been added to the public service in South Africa and this trend of a larger public service must be prevented. This will result in improved spending control. Service delivery, 
especially at the local government sphere must be improved. Public policy such as job creation before welfare extension, public works programmes, special economic development zones, youth development incentives and rural development must be prioritised. Youth unemployment is a major cause for concern. Interventions regarding education, social support, finance and mentorship are needed (CDE, 2012). Improved school-to-job transition is required (OECD, 2010). Youth focused exemptions regarding labour regulations should be allowed (CDE, 2012). In most cases a monetary policy is used to address high levels of unemployment by, for example, a reduction in interest rates. This will stimulate consumer demand and increase production, leading to the creation of jobs. Alternatively, or in support of monetary policy, fiscal policy could be introduced through reduced taxes and/or increased government spending (Amadeo, 2013).

Entrepreneurship development: Entrepreneurship development must be prioritised from as early as possible in order to create awareness regarding self-employment opportunities. Entrepreneurial involvement is relatively low in South Africa if compared to other African countries. Entrepreneurship development must be accelerated and schools, universities, business chambers and government should be involved. The establishment of SMME incubators, job training centres and identification of mentors are important factors for success. In the US, the government has identified new approaches to skills development. Entrepreneurial training must be specifically focused on growth and innovative industries. Research and development in innovation is important (Hackler, 2008). Youth Business International (2013) listed the following recommended actions regarding youth entrepreneurship namely the creation of an improved enabling environment, more focused education, access to finance, mentorship and internet capabilities.

Economic sectoral development: The aim should be to ensure inclusive economic growth and to prevent jobless growth. The job drivers of the NGP should be enhanced further with positive policy direction. All of the job drivers are labour intensive in nature. Further actions include value added incentives, export incentives, improved trade conditions with BRICS partners, a re-focus on the agricultural sector, with agro-processing as a priority sector. Lastly, the manufacturing sector should be supported to improve conditions for growth and employment. According to Hackler (2008), job creation efforts must be linked to economic development efforts. Workforce development must therefore be linked with economic development.

Research and development: More funding should be made available for research and development to universities and other institutions in order to accelerate research regarding job creation initiatives.

\section{Conclusions}

Job creation and sustainable jobs are the result of economic development; while jobs are the foundation of any economy. The lack of jobs leads to poverty, crime and social instability. South Africa has nearly three times the world average unemployment rate, and government has made job creation its number one priority. Government should however appoint only limited numbers of people and leave job creation to the private sector. The government has been responsible for the majority of jobs created since 2005 , but service delivery has not improved as a result. The growth in the public sector is contradictory to the WEF (2011) report on the future of government, as mentioned.

The informal sector in South Africa is under developed and has vast potential to grow if allowed through applicable policies. Barriers to enter the business market need to be removed and SMME and entrepreneurship need to be encouraged and supported.

The vision of the NDP needs to be accepted and supported by all stakeholders. Jobs for all, as an approach, must be implemented, as well as the eight proposed solutions as listed by a strong public, business and community partnership.

\section{References}

Amadeo, K. (2013) Unemployment solutions. Web access: www.useconomy.about.com. Date of access: 19 November 2013.

Banerjee, A., Galiani, S., Levinsohn, J., Mclaren, Z. \& Woolard, I. (2006) Why has unemployment risen in South Africa? International Policy Centre, University of Michigan. Michigan.

Beissinger, T. \& Moeller, J. (2000) Unemployment explanations. In: Wagner, H (Ed.), Globalization and unemployment. Berlin. Springer, pp.89-133.

Borel-Saladin, J.M. \& Turok, I.N. (2013) The impact of the green economy on jobs in South Africa. South African Journal of Science, 109, 9-10.

Calvin, B., \& Coetzee. G. (2010) A review of the South African micro-finance sector volume II. Centre for micro-finance, University of Pretoria, Pretoria.

CDE see Centre for Development and Enterprise.

CIA World Fact Book. (2013) The world fact book. Web access: www.cia.gov/library/publications/the-world-fact-book/fields/2129.html. 
Date of access: 4 September 2013.

Centre for Development and Enterprise (CDE). (2010) A fresh look at unemployment. Web access: www.cde.org.za. Date of access: 21 January 2013.

Centre for Development and Enterprise (CDE). (2011) Jobs for young people: Is wage subsidy a good idea? Web access: www.cde.org.za. Date of access: 7 September 2013.

Centre for Development and Enterprise (CDE). (2012) Coping with unemployment: Young people's strategies and their policy implications. Web access: www.cde.org.za. Date of access: 7 September 2013.

Centre for Development and Enterprise (CDE). (2013) Rethinking South Africa's labour market. Web access: www.cde.org.za. Date of access: 7 September 2013.

Chandra, V., Nganou, J. \& Noel. C. (2002) Constraints to growth in Johannesburg's black informal sector: Evidence from 1999 informal sector survey. World Bank report no 24449-ZA. Washington, DC.

Cloete, N., \& Butler-Adam, J. (2012) Rethinking post-school education and skills training. University World News. 22 July 2012. Issue no 231.

Country economy. (2014) Country statistical comparisons. Web access: www.countryeconomy.com. Date of access: 6 April 2014.

Department of Trade and Industry (DTI). (2013) Industrial policy action plan (IPAP) 2013/14 to 2015/16. Pretoria, Government Printer.

Department of Rural Development and Land Reform (DRDLR). (2010) Comprehensive Rural Development Strategy (CRDP). Pretoria, Government Printer.

DRDLR see Department of Rural Development and Land Reform.

DTI see Department of Trade and Industry.

Du Toit, M. (2012) Job creation: Generating growth and opportunities. Web access: www.deloitte.com/assets/Dcom-SouthAfrica. Date of access: 5 April 2014.

Frost, L. (2002) Finding the top people. HR Future Magazine, 2001,1 (3), pp.30-32.

Fuhrmann, R.C. (2013) Okun's law: Economic growth and unemployment. Web access: www.investopedia.com/articles leconomics/12/okun-law.asp. Date of access: 19 November 2013.

Hackler, D.L. (2008) Creating jobs in America: Case studies in local economic development. Initiative for collaborative government. George Mason University. Fairfax.

Holborn, L. (2012) Employment, South Africa survey, 2012. South African Institute for Race Relations. Johannesburg.

IMF see International Monetary Fund.

International Monetary Fund (IMF). (2013) South Africa searches for faster growth and more jobs. IMF survey. Web access: www.imf.org/external. Date of access: 4 October 2013.

King, I. (2009) Search for a theory of unemployment. Insights, 6, November 2009, pp 23-27.

Kingdon, G. \& Knight, J. (2004) Unemployment in South Africa: the nature of the beast. World Development, 32 (3), $391-408$.

Kingdon, G. \& Knight, J. (2005) Unemployment in South Africa, 1995-2003: causes, problems and policies. Global Poverty Research Group, Oxford University. Oxford.

Kooros, S.K. (2008) In search of a general model of unemployment. Advances in competitiveness research, 16 (1).

Matthews, C. (2012) We have suffered a jobless recovery: Is a recovery without growth next? Time Business. Web access: http://business.time.com. Date of access: 12 September 2012.

McCord, A. (2004) Policy expectations and programme reality: The poverty reduction and labour market impact of two public works programmes in South Africa. ESAU working paper no 8, Overseas Development Institute, London.

McFarland, C. (2011) Local leadership for job creation and economic growth. National League of cities. Web access: www.nlc.org. Date of access: 5 April 2014.

National Treasury. (2012) Estimates of national expenditure. Pretoria, Government Printer.

OECD see Organization for Economic Co-Operation and Development.

Okun, A.M. (1962) Potential GNP, its measurement and significance. Cowles Foundation. Yale University.

Oosthuizen, J. (2013) Let's make entrepreneurship happen. Mail and Guardian, 25 October 2013. Johannesburg.

Organization for Economic Co-Operation and Development (OECD). (2010) Economic surveys: South Africa. Volume 2010/2011, OECD Publishing, Paris.

Ramaphosa, S. (2013) Fixing SA, job by job. City Press, 15 September 2013, p.23. Johannesburg.

Rose, R. (2013). Labour policy is not working. The Sunday Times. 13 October 2013, p.22. Johannesburg.

Schussler, M. (2013) Gehamer op armoede kan boomerang. Sake24. 14 October 2013. Johannesburg.

Statistics South Africa. (2013a) Quarterly labour force survey, quarter 2 of 2013. Pretoria, Government printer.

Statistics South Africa. (2013b) Quarterly labour force survey, quarter 3 of 2013. Pretoria, Government printer.

Statistics South Africa. (2013c) Quarterly employment statistics. June 2013. Pretoria, Government printer.

StatsSA see Statistics South Africa.

Steyn, L. (2012) Job creation still key, but the figures do not tell the story. Mail and Guardian. 24 Feb. 2012, p.4. Johannesburg.

The Presidency. (2011) National development plan (NDP) 2030. National Planning Commission. Pretoria, Government Printer, Republic of South Africa.

Turton, N. \& Herrington, M. (2012) Global entrepreneurship monitor, 2012, South Africa. Graduate School of Business, University of Cape Town. GEM. Cape Town.

UNIDO see United Nations Industrial Development Organization. 
UNDP see United Nations Development Programme.

United Nations Development Programme (UNDP). (2010) Millennium Development Goals: Country report 2010. Web access: www.statssa.gov.za/news_archive/Docs/MDGR_2010.pdf. Date of access: 3 September 2013.

United Nations Industrial Development Organization (UNIDO). (2008) Creating an enabling environment for private sector development in sub-Saharan Africa. Vienna.

WEF see World Economic Forum.

World Bank. (2013) Jobs, a world development report. Washington, DC.

World Bank. (2014). Romania overview. Washington, DC.

World Economic Forum (WEF). (2011) The future of government: lessons learned from around the world. Cologny. Switzerland. Web access: www.weforum.org. Date of access: 19 Nov. 2013.

World Economic Forum (WEF). (2013) The global competitiveness report 2013-2014. Geneva.

Youth Business International (YBI). (2013) Generation entrepreneur? The state of global youth entrepreneurship. Web access: www.gemconsortium.org/docs/download/2835. Date of access: 7 April 2014.

Zuma, J.G. (2011) State of the Nation Address (SONA). Web access: http://www.info.gov.za/speech. Date of access: 12 April 2013. 